Article

\title{
Synthesis and Anticancer Activity of Di(3-thienyl)methanol and Di(3-thienyl)methane
}

\author{
Nagendra Kumar Kaushik ${ }^{1}$, Hong Seon Kim ${ }^{2}$, Young June Chae ${ }^{2}$, Young Nam Lee ${ }^{2}$, \\ Gi-Chung Kwon ${ }^{1}$, Eun Ha Choi ${ }^{1}$ and In Tae Kim ${ }^{2, *}$ \\ 1 Plasma Bioscience Research Center, Kwangwoon University, Seoul 139-701, Korea \\ 2 Department of Chemistry, Kwangwoon University, Seoul 139-701, Korea \\ * Author to whom correspondence should be addressed; E-Mail: itkim@kw.ac.kr; \\ Tel.: +82-10-3795-1479; Fax: +82-2-909-1978.
}

Received: 2 August 2012; in revised form: 24 September 2012 / Accepted: 25 September 2012 / Published: 27 September 2012

\begin{abstract}
Di(3-thienyl)methanol (2) and di(3-thienyl)methane (3) have been synthesized and screened against the T98G (brain cancer) cell line. Treatment induced cell death (MTT and macro-colony assay), growth inhibition, cytogenetic damage (micronuclei formation), were studied as cellular response parameters. Treatment with the compounds enhanced growth inhibition and cell death in a concentration dependent manner in both T98G and HEK (normal) cell lines. At higher concentrations $(>20 \mu \mathrm{g} / \mathrm{mL}$ ) the cytotoxic effects of the compounds were highly significant. The effect on clonogenic capacity and micronuclei formation observed after treatment of cells. Amongst the compounds, compound 2 exhibited potent activity against T98G brain cancer cells. Despite potent in vitro activity, both compounds exhibited less cytotoxicity against normal human HEK cells at all effective concentrations.
\end{abstract}

Keywords: thienyl derivatives; T98G gliomas; HEK cells

\section{Introduction}

The development of new cancer therapeutic agents is one of the fundamental goals in medicinal chemistry. One newer strategy for the research on new antimicrobial therapeutic agents has been the use of $\mathrm{N}$ - and S-containing small heterocyclic compounds. In the race to synthesize new antiproliferative drugs, thiophene derivatives have attracted a great deal of attention amongst the 
scientific community due to their therapeutic uses. The thienyl nucleus is also the core structure of a great number of cancer growth inhibitors. Thiophene and the thienyl core have attracted the attention of the scientific community due to their therapeutic uses as antimicrobial [1], anti HIV [2], PTP1 $\beta$ inhibitors [3], tyrosine kinase inhibitor [4], antioxidant [5,6], anti-inflammatory [5,6], analgesic [5], anti-nociceptive [6], antitubercular [7], antiarrhythemic [8], anticonvulsant [8], antiparasitic [9], anticancer agents [10-12] and metabolic stability in cells [13]. The present work is in continuation of our search for small medicinal active molecules and evaluation of their biological activity. In this present study we describe anticancer activity of two dithienyl derivatives: di(3-thienyl)methanol (2) and di(3-thienyl)methane (3) against T98G brain cancer cells. The cytotoxicity of the synthesized compounds on normal cells were assessed using the HEK cell line, which resembles developing neuron and neuronal stem cells and is also mentioned as good model for neuroscience studies [14]. Based on this background, we have used HEK normal cells as a model for brain normal cells in this study.

\section{Results and Discussion}

\subsection{Synthesis}

We have synthesized $\operatorname{di}(3$-thienyl)methanol (2) and di(3-thienyl)methane (3) and studied their anticancer effects (Scheme 1 and Figure 1). The structures of compound $\mathbf{2}$ and $\mathbf{3}$ are clearly supported by their ${ }^{1} \mathrm{H},{ }^{13} \mathrm{C}-\mathrm{NMR}$ spectra and microanalysis.

Scheme 1. Synthesis of compound 2 and 3.

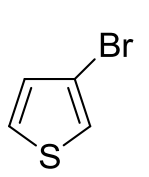

1

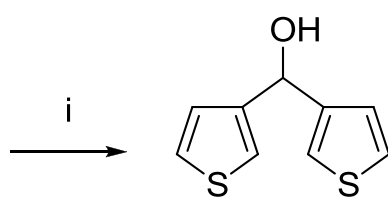

2

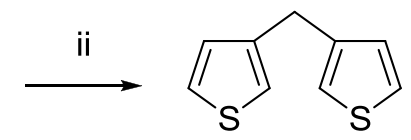

3

Reagents and Conditions: (i) n-butyllithium, ethyl formate, THF, $-78{ }^{\circ} \mathrm{C} \sim \mathrm{RT}, 1 \mathrm{~h}, 88 \%$; (ii) NaI, $\mathrm{Me}_{3} \mathrm{SiCl}, \mathrm{CH}_{3} \mathrm{CN}, 0 \sim 10{ }^{\circ} \mathrm{C}, 0.5 \mathrm{~h}, 90 \%$.

Figure 1. Energy minimized 3D structure of di(3-thienyl)methanol (2) and di(3-thienyl)methane (3). Red, yellow, white color ball represents oxygen, sulfur and hydrogen atoms respectively. Pink balls represent lone pairs on the oxygen atom.

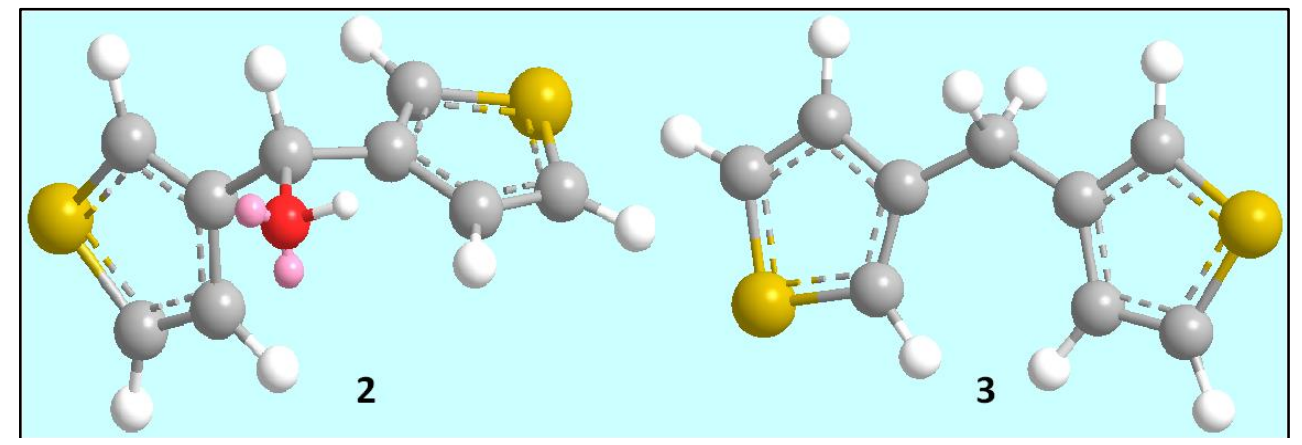




\subsection{MTT Assay}

The 3-(4,5-dimethylthiazol-2-yl)-2,5-diphenyltetrazolium bromide (MTT) cell proliferation assay has been widely accepted as a reliable way to measure the cell proliferation rate and cell death $[15,16]$. The data obtained by MTT assay show that compounds $\mathbf{2}$ and $\mathbf{3}$ have inhibitory effects on the growth of T98G and HEK cells in dosage-dependent manners. Compounds $\mathbf{2}$ and $\mathbf{3}$ can inhibit 50\% T98G cell growth ( $\mathrm{IC}_{50}$ ) obviously in the $60-200 \mu \mathrm{g} / \mathrm{mL}$ range after 24,48 and $72 \mathrm{~h}$ of the treatment (Figure 2). Maximum inhibitory effect was shown by compound 2 on T98G cells after $72 \mathrm{~h}$ of treatment, however compound $\mathbf{3}$ also effectively inhibits the growth of T98G cells at all the concentrations $(0.7-2,500 \mu \mathrm{g} / \mathrm{mL})$ and without any time dependent effects (Figure 2). Overall compound 2 was the most potent one, having significant a inhibitory effect on T98G cells growth. Both compounds are less toxic to the HEK cells with $75 \%-97 \%$ viability at $60 \mu \mathrm{g} / \mathrm{mL}$ concentration at all time intervals, which further increased by decreasing the concentration of the compounds (Figure 2). For further studies, we have selected compound $\mathbf{2}$ on the basis of its significant toxicity against T98G brain cancer cells.

Figure 2. \% Viability evaluated from MTT assay on T98G brain cancer and normal HEK cells treated with thienyl derivative for 24,48 , and $72 \mathrm{~h}$.

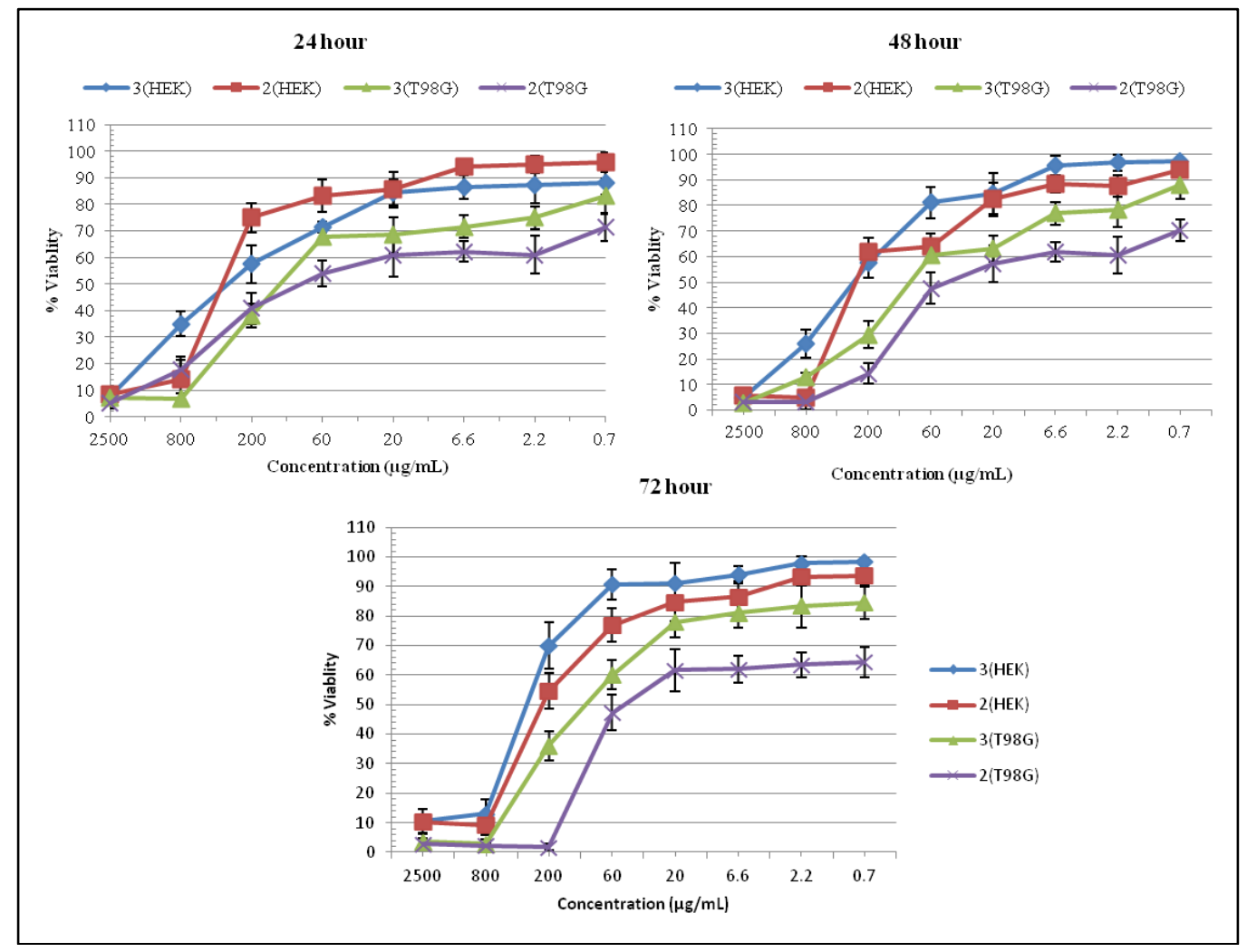

\subsection{Growth Kinetics Assay}

Figure 3 shows the growth kinetics of $\mathrm{T} 98 \mathrm{G}$ cells treated with compound 2. Cell proliferation kinetics have been studied at $24,48,72 \mathrm{~h}$ after compound treatment, following trypsinization and counting total cells per plate by using a trypan blue dye and hemocytometer. Data obtained from the growth kinetics assay shows that compound $\mathbf{2}$ has inhibitory effects on the growth of T98G cells in a concentration dependent manner. 
Figure 3. Growth kinetics of T98G cells at 24,48 and $72 \mathrm{~h}$ after treatment by compound 2 at $2.2-200 \mu \mathrm{g} / \mathrm{mL}$ concentrations. Untreated cells are taken as control and all values given as mean $( \pm \mathrm{SE})$ of three independent experiments, $n=3$.

\section{Growth Kinetics-T98G cells}

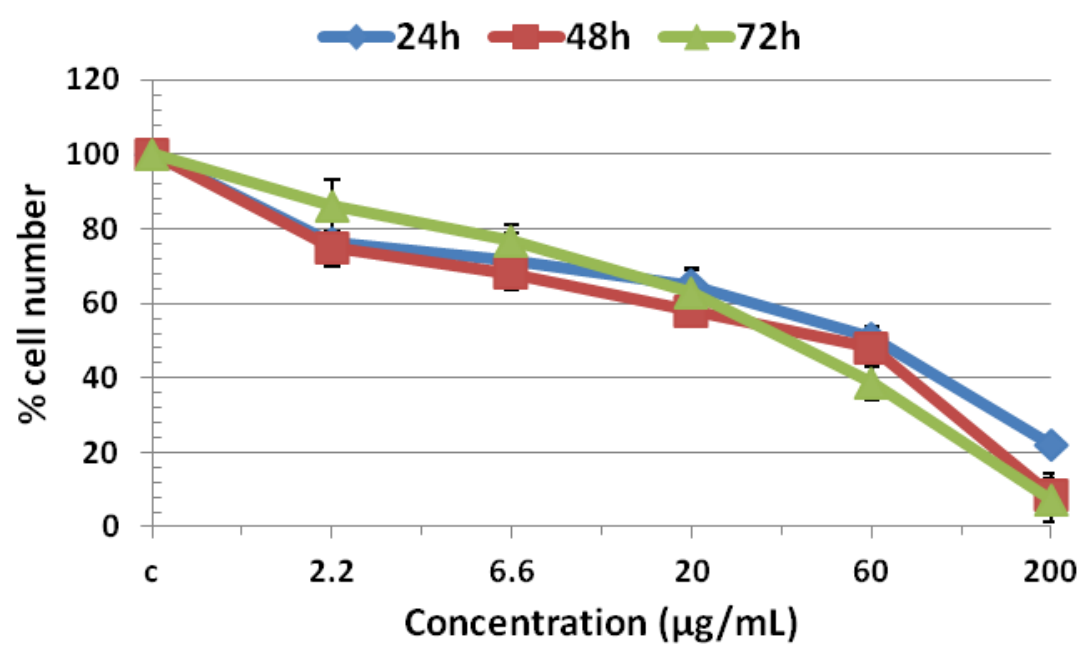

It was also noted that the cells exposed to 2.2 and $6.6 \mu \mathrm{g} / \mathrm{mL}$ concentrations show less growth inhibitory effects than those treated with 20,60 and $200 \mu \mathrm{g} / \mathrm{mL}$ concentration. Maximum effect was shown by $200 \mu \mathrm{g} / \mathrm{mL}$ concentration of compound 2, which inhibits the growth of cells up to $93 \%$ at 48 and $72 \mathrm{~h}$ after treatment and its viability range was $7 \%-8 \%$. In the case of 20 and $60 \mu \mathrm{g} / \mathrm{mL}$ exposures, we found $45 \%-60 \%$ cells death at all time intervals. Cell morphology analysis revealed that shape and size of viable cells were also affected by treatment of compound 2 (Figure 4). From Figure 4 it is found that there was remarkable differences in shape and size of treated cells at 2.2, 20, 60 and $200 \mu \mathrm{g} / \mathrm{mL}$ after treatment.

Figure 4. Morphology of compound 2 treated T98G brain cancer cells at $24 \mathrm{~h}$ after treatment. Cells were treated at concentration 2.2, 6.6, 20, 60 and $200 \mu \mathrm{g} / \mathrm{mL}$.
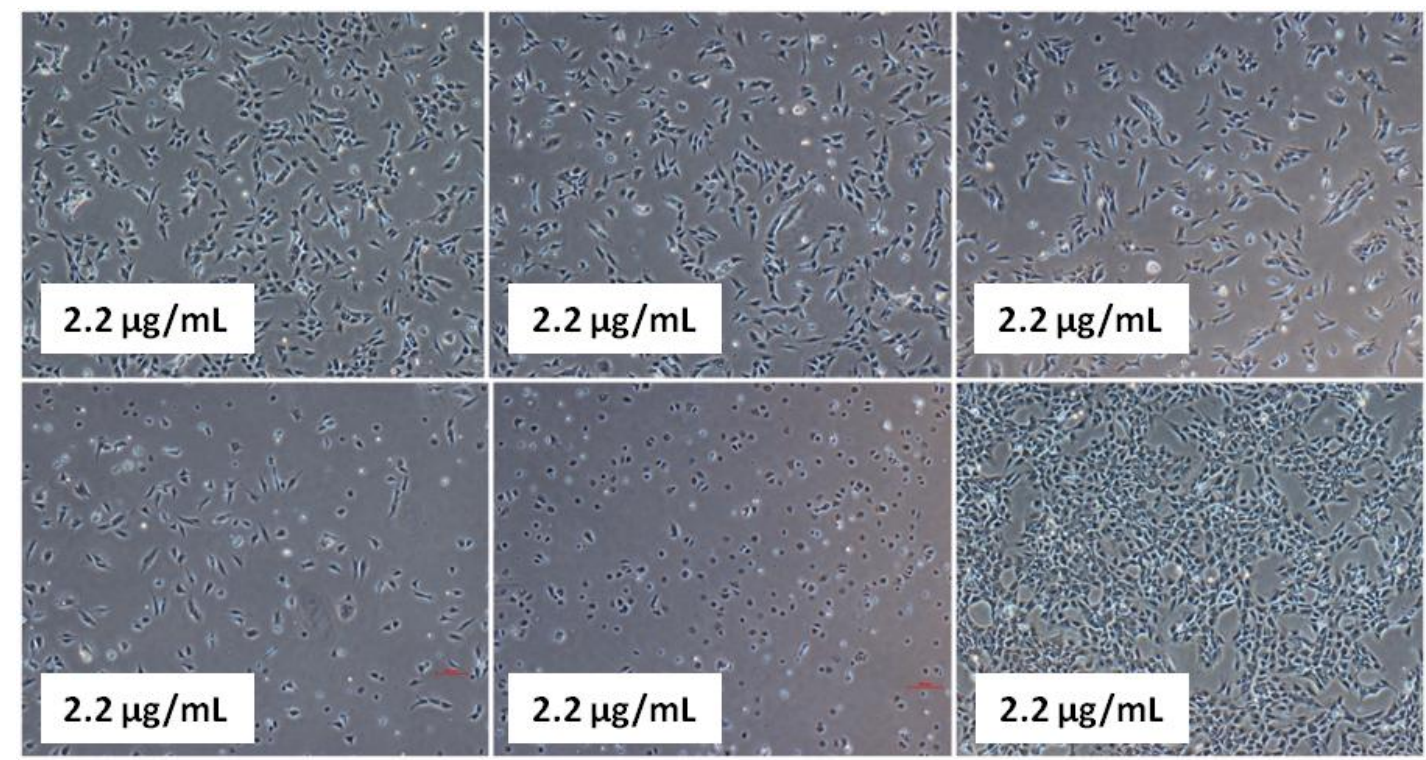


\subsection{Clonogenic Assay}

The clonogenic assay shows the effect of compound $\mathbf{2}$ on the colony-forming capacity and survival of exponentially growing T98G cells. We have used the clonogenic assay for confirming the growth inhibition results of compound 2. Clonogenic assay or colony formation assay is an in vitro assay based on the ability of a single cell to grow into a colony. Only a fraction of seeded cells retains the capacity to produce colonies after cytotoxic drug treatment. As observed in Figure 5, the surviving fraction of T98G cells has been drastically decreased after its treatment by compound $\mathbf{2}$. Compound 2 treatment enhances cell death and also inhibits colony formation capability in the T98G cell population in a concentration dependent manner. After treatments with different concentrations $(2.2-200 \mu \mathrm{g} / \mathrm{mL})$, the surviving fraction of T98g cells declines, as evidenced by the reduction in the number of colonies formed. Even at low doses, 2.2, 6.6 and $20 \mu \mathrm{g} / \mathrm{mL}$ exposure of compound 2 shows a significant decline in colony survival and the surviving fractions was found to be $0.85,0.71$ and 0.58 , respectively. However, a significant drastic decline in their surviving fraction could be observed after exposure to 60 and $200 \mu \mathrm{g} / \mathrm{mL}$ treatment and their surviving fractions were found to be 0.32 and 0 (zero), respectively. This shows that these treatments significantly inhibit the colony formation capabilities of brain cancer cells at all the dosages.

Figure 5. Effect of compound 2 on colony forming capacity and survival of exponentially growing T98G cell lines studied by macro colony assay. Data presented are mean values from three independent observations, $\mathrm{n}=3$.

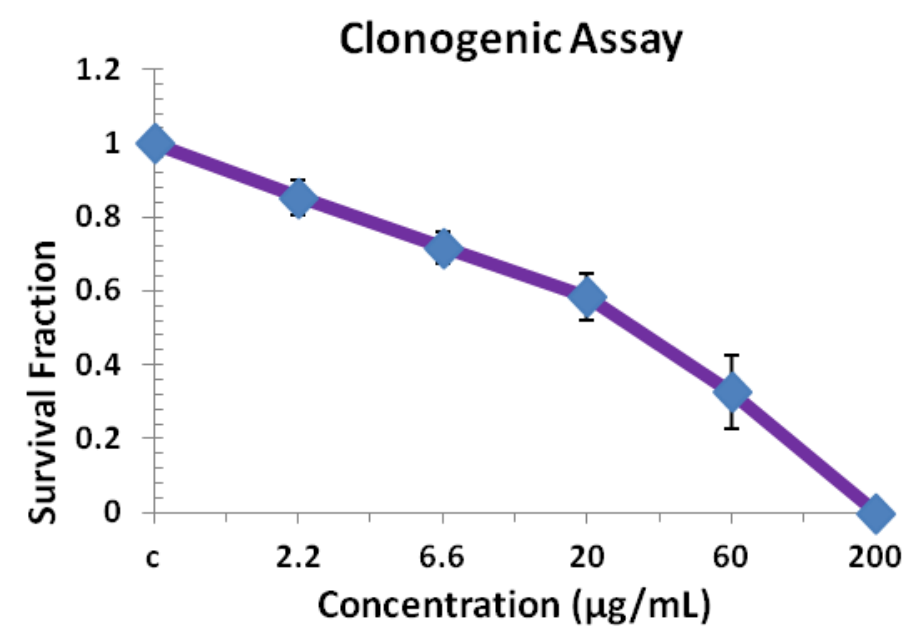

\subsection{Micronucleus Assay}

In recent years, the in vitro micronucleus (MN) assay has become an attractive tool for measuring genotoxicity by physical and chemical agents, due to its capacity to detect clastogenic and aneugenic events, simplicity of scoring, accuracy, multipotentiality and wide applicability in different cell types. For measuring micronucleus, we have treated T98G cells with compound $\mathbf{2}$ under similar conditions and concentrations to those which were used in earlier experiments on growth kinetics and the clonogenic assay. After treatment by compound 2, cell cultures were grown for a 24 and $48 \mathrm{~h}$ in order 
to allow chromosomal damage leading to the formation of micronuclei in bi- or multinucleated interphase cells.

Figure 6 shows the micronucleus frequency at 24 and $48 \mathrm{~h}$ for T98G brain cancer cell after treatment with $2.2-60 \mu \mathrm{g} / \mathrm{mL}$ concentration of compound 2 . The frequency of untreated cells with micronuclei were in the range of 3.5\%-3.9\%; whereas the treatment with $2.2 \mu \mathrm{g} / \mathrm{mL}$ does not induce any significant level of micronuclei formation in $\mathrm{T} 98 \mathrm{G}$ cells, and the range of micronucleus is 3.8-3.9. However, micronuclei frequency increased from 3.5\% (control) to 5.6\%, $6.21 \%$ and $7.7 \%$ for 6.6, 20 and $60 \mu \mathrm{g} / \mathrm{mL}$ concentration treated cells, respectively, at $24 \mathrm{~h}$ of culture. However, it was increased further at $48 \mathrm{~h}$ of culture as $6.6,20$ and $60 \mu \mathrm{g} / \mathrm{mL}$ concentrations of compound 2 further increased micronuclei frequency from $3.9 \%$ (control) to $5.9 \%, 6.43 \%$ and $7.9 \%$, respectively. Micronuclei shown in compound 2 treated T98G cells were formed by DNA strand breaks generated during the faulty excision repair process. The remaining unsealed DNA leads to the formation of micronuclei in subsequent mitosis, and cells with micronuclei are found to be associated with loss of reproductive capacity.

Figure 6. Comparison between micronucleus (MN) frequencies at 24 and $48 \mathrm{~h}$ in human T98G cells treated with compound 2. Whereas 'Control' is micronuclei frequency of untreated cells.Results are measured in vitro both in mononucleated cells and binucleated cells in cultures. These cells shown with one or many micronucleus were scored for MN frequency. The data represents mean $\pm S E M, n=3$.

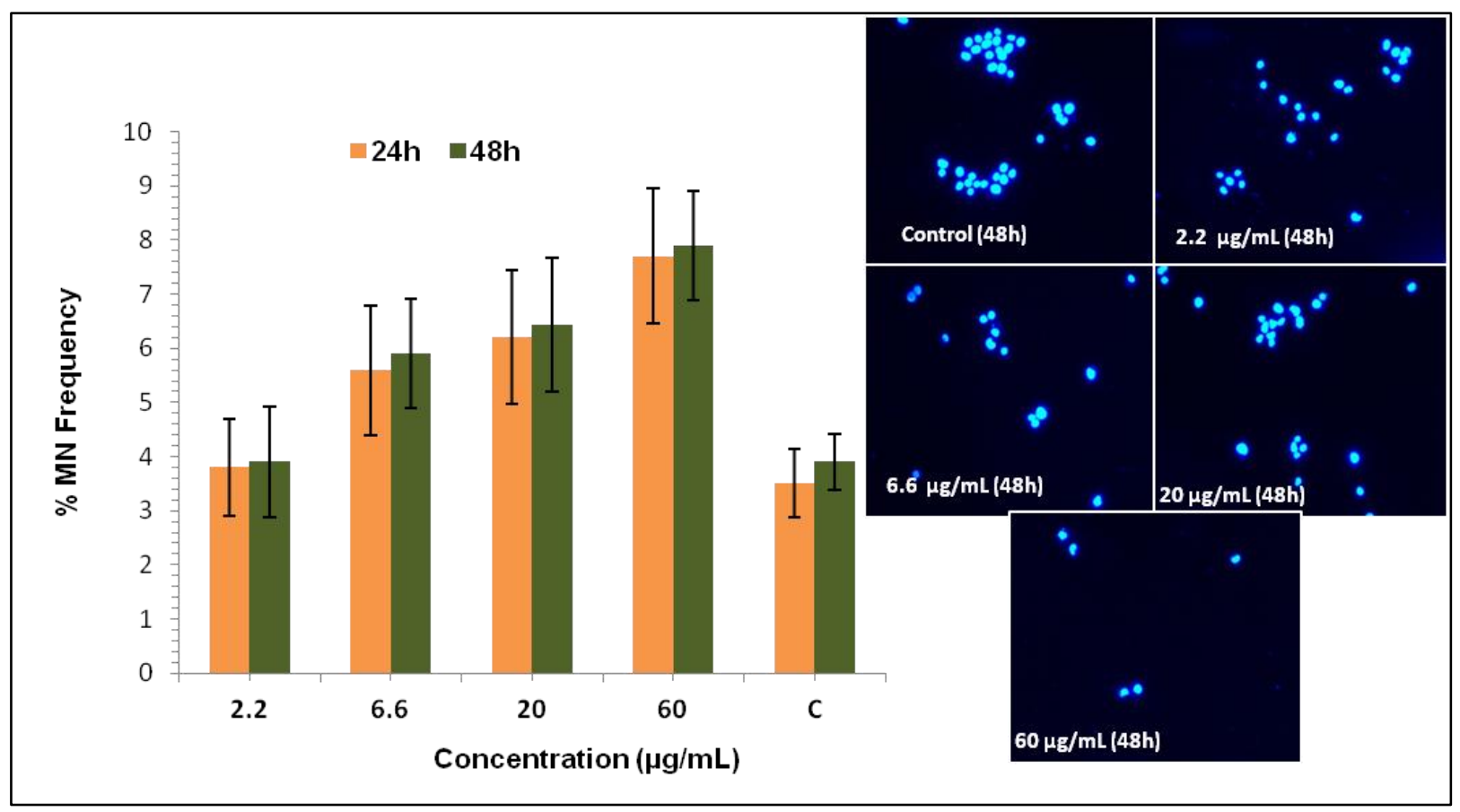

\subsection{In Silico Pharmacokinetics}

For a molecule to be a probable drug, besides having a good biological activity, it must have nice pharmacokinetic accessibility in biological systems. To access the pharmacokinetic profile of the synthesized molecule, we used the well validated in silico tools: Osiris, Chemaxon and Catalyst. These tools have been validated with almost 7,000 drug molecules available in market. The analysis of 
theoretical toxicity risks for the thienyl derivatives using the OSIRIS program shows that all compounds were less toxic and can be used as a therapeutic molecules (Figure 7). As these compounds are considered for oral delivery, they were submitted to the analysis of Lipinski 'rule of five', druglikness and drug score by using the Catalyst software (Table 1).

Figure 7. In silico drug safety analysis for thienyl derivatives by Osiris software.

\section{In silico risk of Toxicity Evaluation by Osiris Software}

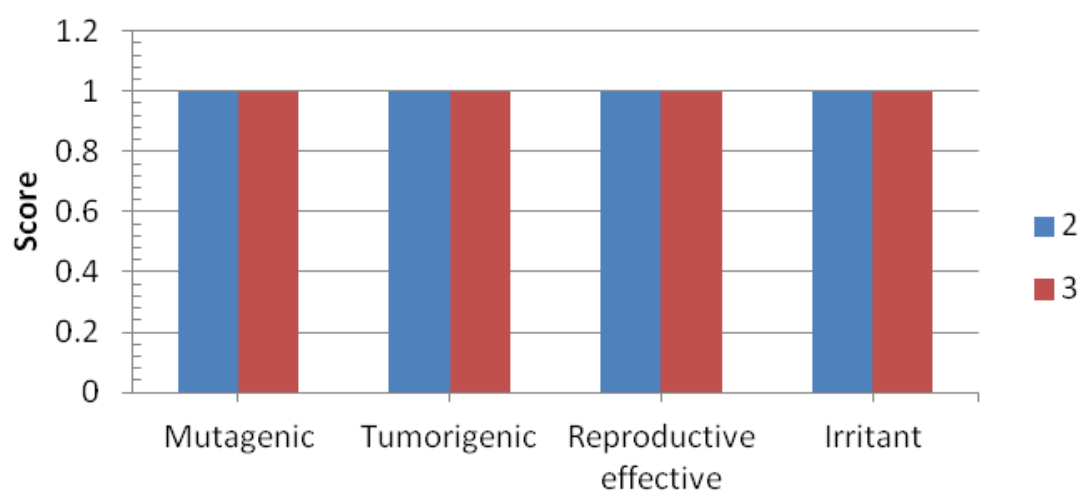

Our results pointed that all effective compounds fulfill this rule and their druglikness property such as molecular weight (180-196), Log P (2.38-3.13), nHBA (0-1), nHBD (0-1) and number of rotatable bonds (rotb) (2) were better than commercial drugs (Table 1). Finally, we evaluated thienyl derivative 2 as a potential drug by calculating druglikeness and drug-score. Druglikeness, which is related to the similarity with trade drugs (-1.28-1.29). Drug score of all derivatives was in the range of 0.46-0.56. Among the both thienyl compounds, 2 showed the best values of drug-score (0.56) with a lower toxicity effect, which suggests it should be considered for further in vivo exploration.

Table 1. Pharmacokinetic parameters (Catalyst, Chemaxon and Osiris softwares).

\begin{tabular}{cccccccc}
\hline Compounds & nHba & nHbd & nrotb & MW & cLog P & Druglikeness & Drug Score \\
\hline 2 & 1 & 1 & 2 & 196 & 2.38 & -1.29 & 0.56 \\
3 & 0 & 0 & 2 & 180 & 3.13 & -2.28 & 0.47 \\
\hline
\end{tabular}

\section{Experimental}

\subsection{General}

The MTT (3-[4,5-dimethylthiazol-2-yl]-2,5-diphenyltetrazolium bromide), bisbenzimidazole derivative Hoechst-33342 (bis-benzimide(2-[4-ethoxyphenyl]-5-[4- methyl-1-piperazinylpiperazinyl]2,5-bi-1H-benzimidazole)trihydrochloride), Hank's balanced salt solution (HBSS), Dulbecco's modified phosphate buffered saline (PBS), Dulbecco's modified eagle's medium (DMEM), fetal calf serum (FCS), N-[2-hydroxyethyl]piperazine-N-[2-ethanesulfonic acid] (HEPES) buffer, propidium iodide (PI), Ribonuclease-A (RNase-A), trihydro-chloride, propidium iodide and trypsin were obtained from the Sigma Chemical Co., USA. All other chemicals used in the present study were of analytical grade. 


\subsection{Preparation of Di(3-thienyl)methanol (2)}

3-Bromothiophene $(\mathbf{1}, 60 \mathrm{~g}, 0.36 \mathrm{~mol})$ was added into a solution of $n$-butyllithium $(0.36 \mathrm{~mol})$ in THF (120 mL) at $-78{ }^{\circ} \mathrm{C}$ and a solution of the ethyl formate $(13.63 \mathrm{~g}, 0.184 \mathrm{~mol})$ in THF (60 mL) was added dropwise while maintaining the temperature between -78 and $-70{ }^{\circ} \mathrm{C}$ [17]. The mixture was then allowed to warm slowly (over $\sim 1 \mathrm{~h}$ ) to RT. The resulting mixture was hydrolyzed with $10 \%$ aqHCl (76.8 g) with cooling below $0{ }^{\circ} \mathrm{C}$. The organic layer was separated, and the aqueous layer was extracted with $\mathrm{CHCl}_{3}(300 \mathrm{~mL} \times 3)$. The combined solutions were dried with $\mathrm{Na}_{2} \mathrm{SO}_{4}$ and concentrated in vacuo. The residue was chromatographed on a short silica gel column (hexane-EA 6:1) to yield a pale-yellow viscous oil, which solidified upon standing. Yield: $88 \%$ (31.78 g); m.p. 61-62 ${ }^{\circ} \mathrm{C}$. ${ }^{1} \mathrm{H}-\mathrm{NMR}\left(400 \mathrm{MHz}, \mathrm{CDCl}_{3}\right): 7.19(\mathrm{dd}, 2 \mathrm{H}, J=5.0,3.0 \mathrm{~Hz}), 7.07(\mathrm{~m}, 2 \mathrm{H}), 6.93(\mathrm{dd}, 2 \mathrm{H}, J=5.0$, $1.3 \mathrm{~Hz}$ ), 5.76 (s, 1H), 3.10 (br s, $1 \mathrm{H}) ;{ }^{13} \mathrm{C}-\mathrm{NMR}$ (100 MHz, $\mathrm{CDCl}_{3}$ ): 144.71 (2C), 126.26 (2C), 125.94 (2C), 121.50(2C), 68.67. Anal Calcd for $\mathrm{C}_{9} \mathrm{H}_{8} \mathrm{OS}_{2}: \mathrm{C}, 55.07 ; \mathrm{H}, 4.11$ Found: C, 54.88; H,4.17.

\subsection{Preparation of Di(3-thienyl)methane (3)}

To a well stirred solution of chlorotrimethylsilane $(55.34 \mathrm{~g}, 0.5094 \mathrm{~mol})$ in anhydrous $\mathrm{CH}_{3} \mathrm{CN}(240 \mathrm{~mL})$ was added $\mathrm{NaI}(76.35 \mathrm{~g}, 0.5094 \mathrm{~mol})$ in one portion. The resulting slurry was stirred for $20 \mathrm{~min}$ at $0{ }^{\circ} \mathrm{C}$, and then a solution of corresponding di(3-thienyl) methanol $(2,20 \mathrm{~g}, 0.1018 \mathrm{~mol})$ in $\mathrm{CH}_{3} \mathrm{CN}$ $(150 \mathrm{~mL})$ was added dropwise over $30 \mathrm{~min}$ to maintain the reaction temperature below $10{ }^{\circ} \mathrm{C}$ [18]. The reaction mixture was quenched with aqueous $\mathrm{NaOH}(10.99 \mathrm{~g}$ in $150 \mathrm{~mL})$ extracted with $\mathrm{CH}_{2} \mathrm{Cl}_{2}$ $(300 \mathrm{~mL} \times 3)$, washed with a saturated solution of $\mathrm{Na}_{2} \mathrm{~S}_{2} \mathrm{O}_{3} \cdot 5 \mathrm{H}_{2} \mathrm{O}(150 \mathrm{~mL})$, and dried over $\mathrm{Na}_{2} \mathrm{SO}_{4}$. Organic solvents were removed in vacuo, and the brown residue was purified by column chromatography (hexane) to yield the pure di(3-thienyl)methane (3) as a white solid or pale yellow oil which solidified upon standing. Yield: $90 \%$ (16.51 g); m.p. $35-36{ }^{\circ} \mathrm{C} .{ }^{1} \mathrm{H}-\mathrm{NMR}\left(400 \mathrm{MHz}, \mathrm{CDCl}_{3}\right)$ : 7.38 (dd, 2H), 7.09 (m, 2H), 4.14 (s, 2H); ${ }^{13} \mathrm{C}-\mathrm{NMR}$ (100 MHz, $\mathrm{CDCl}_{3}$ ): 140.75 (2C), 128.21 (2C), 125.42 (2C), 121.00(2C), 30.89. Anal Calcd for $\mathrm{C}_{9} \mathrm{H}_{8} \mathrm{OS}_{2}$ : C, 59.96; H, 4.47 Found: C, 59.74; H, 4.19.

\subsection{Human Cell Culture}

T98G (brain cancer) and HEK Normal (Human Embryonic Kidney) cells were used in the present studies were purchased from SNU (Seoul, Korea). We were culture these cell line in $75 \mathrm{~cm}^{2}$ culture flasks (Corning, New York, NY, USA) using Dulbecco's modified Eagle's medium (DMEM) supplemented with $10 \%$ fetal bovine serum, $1 \%$ nonessential amino acids, $1 \%$ glutamine, penicillin (100 IU/mL) and streptomycin $(100 \mathrm{mg} / \mathrm{mL}$ ) (all from Euroclone, UK) or by distributor instructions. All cultures were maintained at $37{ }^{\circ} \mathrm{C}, 95 \%$ relative humidity and $5 \% \mathrm{CO}_{2}$. Prior to each cytotoxicity test, the cells were harvested using trypsin-ethylenediaminetetraacetic acid (EDTA)-PBS solution (with $0.25 \%$ trypsin- $0.05 \mathrm{mM}$ according to the distributor's instructions) and diluted at a density of $5 \times 10^{5}$ cells $/ \mathrm{mL}$ in MTT assays. Stock cultures were passaged every third day after harvesting the cells with $0.05 \%$ trypsin and seeding $8 \times 10^{3}$ cells $/ \mathrm{cm}^{2}$ in tissue culture flasks to maintain the cells in the exponential phase. All experiments were carried out in exponentially growing cells. The cell suspension was seeded into 24-well plates (Corning, New York, NY, USA) at $100 \mu \mathrm{L}$ well, and incubated for approximately 20-24 h before tests in order to reach confluency. Before the cells were 
seeded into 24 -well plates, the plates were treated with $0.01 \%$ poly-D-lysine solution (Sigma-Aldrich, Germany).

\subsection{In Vitro Cell Viability Assay}

Cells were seeded in 24-well plates at a concentration of $2-4 \times 10^{3}$ cells/well in $200 \mu \mathrm{L}$ of complete media and incubated for $24 \mathrm{~h}$ at $37{ }^{\circ} \mathrm{C}$ in $5 \% \mathrm{CO}_{2}$ atmosphere to allow for cell adhesion. All assays were performed in two independent sets of quadruplicate tests. Control group containing without treatment was run in each assay. Following after 24, 48 and $72 \mathrm{~h}$ of exposure of cells to compound, each well will be carefully rinsed with $200 \mu \mathrm{L}$ PBS buffer. Cytotoxicity were assessed using MTT (3-[4,5-dimethylthiazol-2yl]-2,5-diphenyltetrazolium bromide). MTT solutions $20 \mu \mathrm{L}\left(5 \mathrm{mg} \cdot \mathrm{mL}^{-1} \mathrm{dd}\right.$ $\mathrm{H}_{2} \mathrm{O}$ ) along with $200 \mu \mathrm{L}$ of fresh, complete media were added to each well and plates were incubated for $3 \mathrm{~h}$ [19]. Following incubation, the medium were removed and the purple formazan precipitate in each well were sterilized in $200 \mu \mathrm{L}$ DMSO. Absorbances were measured using microplate reader at $570 \mathrm{~nm}$ and results were expressed as \% viability which is directly proportional to metabolic active cell number. Percentage (\%) viability was calculated as:

$\%$ Viability $=$ OD in sample well/OD in control well $\times 100$

\subsection{Cell Growth Kinetics Assay}

Cells were seeded at 7,000-10,000 cells $/ \mathrm{cm}^{2}$ in $90-120 \mathrm{~mm}$ Petri dishes or flasks, and their proliferation kinetics will be studied at $24,48,72 \mathrm{~h}$ after treatment by compounds, following trypsinization and counting total cells per flask/disc by using a Neubauer hemocytometer.

\subsection{Clonogenic Survival Assay}

Clonogenic assay or colony formation assay is an in vitro cell survival assay based on the ability of a single cell to grow into a colony. The colony is defined to consist of at least 50 cells. The assay essentially tests every cell in the population for its ability to undergo "unlimited" division [20]. Clonogenic assay is the method of choice to determine cell reproductive death after treatment with ionizing radiation, but we can also be used to determine the effectiveness of drug molecules. Only a fraction of seeded cells retains the capacity to produce colonies before or after treatment, cells will be seeded out in appropriate dilutions to form colonies in 1-3 weeks. After harvesting with $0.05 \%$ trypsin, 150-400 (depending on the treatment) cells will be plated 10-14 h before treatment in DMEM at $37{ }^{\circ} \mathrm{C}$. Cultured cells will be treated with doses 20 to $100 \mathrm{ug} / \mathrm{ml}$ of compounds. After the treatment, cells will be incubated in dark under humidified, $5 \% \mathrm{CO}_{2}$ atmosphere at $37{ }^{\circ} \mathrm{C}$ for $8-10$ days to allow colony formation. Colonies will be fixed with methanol and will be stained with $1 \%$ crystal violet. Colonies of more than 50 cells will be counted and the surviving fraction (SF) will calculated. Clonogenic survival curves will be constructed from three independent experiments by least-squares regression fitting averaged survival levels. 


\subsection{Micronuclei Formation}

The purpose of the micronucleus assay is to detect those chemical and physical agents which modify chromosome structure and segregation in cells [21]. For measuring micronucleus we treated T98G cells by compound under similar conditions as we used in earlier experiments for growth kinetics and clonogenic assay. After treatment by compound, cell cultures are grown for a 24 and $48 \mathrm{~h}$ to allow chromosomal damage to lead to the formation of micronuclei in bi- or multinucleated interphase cells. Air-dried slides containing acetic acid-methanol (1:3 V/V) fixed treated cells were stained with Hoechst-33342 $(10 \mu \mathrm{g} / \mathrm{mL}$ in PBS $(0.1 \mathrm{M})$, disodium phosphate $(0.45 \mathrm{M})$ buffer containing $0.05 \%$ Tween-20 detergent). Slides were examined under the fluorescence microscope using an UV excitation filter. Fluorescent nuclei were visualized using a blue emission filter. Cells containing micronuclei were counted from $>1,000$ cells by employing the criteria of Countrymen and Heddle [21].

The fraction of cells containing micronuclei, called the M-fraction (\%) or MN frequency was calculated as follows:

$$
\text { M-fraction }(\%)=N \mathrm{~m} / \mathrm{Nt} \times 100
$$

where $\mathrm{Nm}$ is the number of cells with micronuclei and $\mathrm{Nt}$ is the total number of cells analyzed. Since, micronuclei formation is linked to cell proliferation, the micronuclei frequencies were normalized with respect to the cell numbers.

\subsection{In Silico Pharmacokinetic Screening}

To evaluate pharmacokinetic profile descriptors such as cLogP (octanol/water partition coefficient) and $\operatorname{LogS}$ (water solubility) were calculated using the Osiris Property Explorer on-line system [22]. The thienyl derivatives were submitted to in silico absorption, distribution, metabolism, excretion, and toxicity (ADMET) screening, using the Osiris program. Values of druglikeness are based on the occurrence frequency of each fragment of the molecule in commercial drugs while the drug-score evaluates the compound's potential to qualify for a drug and is related to topological descriptors, fingerprints of molecular druglikeness, structural keys and other properties such as cLog $\mathrm{P}$ and molecular mass [22,23]. In silico theoretical safety analysis is also evaluated by Osiris software, whereby a score of 1 means a drug is safe and a score $<1$ means a drug molecule is theoretically toxic in use. The pharmacokinetic profile, important for a good oral bioavailability of a compound, was also evaluated according to the Lipinski's 'rule-of-five' by using the Catalyst and Chemaxon softwares, which analyse features that a drug should present to allow the absorption and permeation across the membranes and states molecular weight $<500$ Daltons (Da), calculated octanol/water partition coefficient $(\operatorname{cog} \mathrm{P})<5$, number of hydrogen-bond acceptors $(\mathrm{nHba})<10$, and number of hydrogen-bond donors $(\mathrm{nHbd})<5[22,23]$, as well as a fifth rule added later, which infers the number of rotatable bonds $<10$. 


\section{Conclusions}

The obtained results for human T98G brain cancer cells were compared with Human Embryonic Kidney (HEK) cells. The compounds were more efficacious on T98G cancer cells and are less toxic to normal human HEK cells. These thienyl derivatives may be regarded as lead structures for a new class of anticancer agents with both drug delivery capability because of small size and capable of chemosensitization. Finally we can conclude that compound $\mathbf{2}$ and $\mathbf{3}$ could have the broad dosage ranges of activity against human T98G brain cancer cells. Compound $\mathbf{2}$ shows significant toxicity on T98G cells and the least toxicity on normal HEK cells. Compound $\mathbf{2}$ also inhibits the clonogenic capacity of T98G brain cancer cells in a concentration dependent manner. Compound $\mathbf{2}$ presents the overall best parameters including: (a) high activity against a brain cancer cell line, (b) low cytotoxicity risks in HEK cells, (c) low toxic effect risks in in silico analysis, (d) good oral bioavailability according to the Lipinski 'rule of five', and (e) better druglikeness and drug-score values, nearly similar or better than some commercial drugs. Studies on the mechanism by which the compound 2 induce antiproliferative effect on T98G brain cancer cells and a wider range of other cancer cell lines are ongoing.

\section{Acknowledgments}

The present research has been conducted by the Research Grant of Kwangwoon University in 2011 and SRC program of National Research Foundation of Korea (20100029418) in 2012. This work was supported by the New \& Renewable Energy of the Korea Institute of Energy Technology Evaluation and Planning (KETEP) grant funded by the Korea government Ministry of Knowledge Economy (No. 96002011003) and by Ministry of Knowledge Economy (MKE), Korea as a project, "Full color 360 degree 3D holographic video making technology".

\section{References}

1. Elsabee, M.Z.; Ali, E.A.; Mokhtar, S.M.; Eweis, M. Synthesis, characterization polymerization and antibacterial properties of novel thiophene substituted acrylamide. React. Funct. Polym. 2011, 71, 1187-1194.

2. Bonini, C.; Chiummiento, L.; Bonis, M.D.; Funicello, M.; Lupattelli, P.; Suanno, G.; Berti, F.; Campaner, P. Synthesis, biological activity and modelling studies of two novel anti HIV PR inhibitors with athiophene containing hydroxyethylamino core. Tetrahedron 2005, 61, 6580-6589.

3. Ye, D.; Zhang, Y.; Wang, F.; Zheng, M.; Zhang, X.; Luo, X.; Shen, X.; Jiang, H.; Liu, H. Novelthiophene derivatives as PTP1B inhibitors with selectivity and cellular activity. Bioorg. Med. Chem. 2010, 18, 1773-1782.

4. Brandt, W.; Mologni, L.; Preu, L.; Lemcke, T.; Gambacorti-Passerini, C.; Kunick, C. Inhibitors of the RET tyrosine kinase based on a 2-(alkylsulfanyl)-4-(3-thienyl)nicotinonitrile scaffold. Eur. J. Med. Chem. 2010, 45, 2919-2927.

5. Abdel-Wahab, B.F.; Abdel-Gawad, H.; Ghada, E.A.A.; Badria, F.A. Synthesis, antimicrobial, antioxidant, antiinflammatory and analgesic activities of some new 3-(2'-thienyl)pyrazolebased heterocycles. Med. Chem. Res. 2012, 21, 1418-1426. 
6. Meotti, F.C.; Silva, D.O.; Santos, A.R.S.D.; Zeni, G.; Rocha, J.B.T.; Nogueira, C.W. Thiopheneand furans derivatives: A new class of potential pharmacological agents. Environ. Toxicol. Pharmacol. 2003, 15, 37-44.

7. Lu, X.; Wan, B.; Franzblau, S.G.; You, Q. Design, synthesis and anti-tubercular evaluation of new 2-acylated and 2-alkylated amino-5-(4-(benzyloxy)phenyl)thiophene-3-carboxylic acid derivatives. Eur. J. Med. Chem. 2011, 46, 3551-3563.

8. Amr, A.E.G.E.; Sherif, M.H.; Assy, M.G.; Al-Omar, M.A.; Ragab, I. Antiarrhythmic, serotonin antagonist and antianxiety actvities of novel substitutedthiophene derivatives synthesized from 2-amino-4,5,6,7-tetrahydro-N-phenylbenzo[b]thiophene -3-carboxamide. Eur. J. Med. Chem. 2010, 45, 5935-5942.

9. Gonzalez, J.L.; Stephens, C.E.; Wenzler, T.; Brun, R.; Tanious, F.A.; Wilson, W.D.; Barszcz, T.; Werbovetz, K.A.; Boykin, D.W. Synthesis and antiparasitic evaluation of bis-2,5-[4guanidinophenyl] thiophene. Eur. J. Med. Chem. 2007, 42, 552-557.

10. Romagnoli, R.; Baraldi, P.G.; Carrion, M.D.; Cara, C.L.; Cruz-Lopez, O.; Preti, D.; Tolomeo, M.; Grimaudo, S.; Cristina, A.D.; Zonta, N.; et al. Design, synthesis, and biological evaluation of thiophene analogues of chalcones. Bioorg. Med. Chem. 2008, 16, 5367-5376.

11. Diana, P.; Carbone, A.; Barraja, P.; Montalbano, A.; Martorana, A.; Dattolo, G.; Gia, O.; Via, L.D.; Cirrincione, G. Synthesis and antitumor properties of 2,5-bis(3'-indolyl)thiophenes: Analogues of marine alkaloid nortopsentin. Bioorg. Med. Chem. Lett. 2007, 17, 2342-2346.

12. Gouda, M.A.; Berghot, M.A.; Baz, E.A.; Hamama, W.S. Synthesis, antitumor and antioxidant evaluation of some new thiazole and thiophene derivatives incorporated coumarin moiety. Med. Chem. Res. 2012, 21, 1062-1070.

13. Scarpelli, R.; Marco, A.D.; Ferrigno, F.; Laufer, R.; Marcucci, I.; Muraglia, E.; Ontoria, J.M.; Rowley, M.; Serafini, S.; Steinkühler, C.; et al. Studies of the metabolic stability in cells of 5-(trifluoroacetyl)thiophene-2-carboxamides and identification of more stable class II histone deacetylase (HDAC) inhibitors. Bioorg. Med. Chem. Lett. 2008, 18, 6078-6082.

14. Shaw, G.; Morse, S.; Ararat, M.; Graham, F.L. Preferential transformation of human neuronal cells by human adenoviruses and the origin of HEK 293 cells. FASEB J. 2002, 16, 869-871.

15. Kaushik, N.K.; Kim, Y.H.; Han, Y.G.; Choi, E.H. Effect of jet plasma on T98G human brain cancer cells. Curr. Appl. Phys. 2013, 13, 176-180.

16. Mishra, A.; Jung, H.; Park, J.W.; Kim, H.K.; Kim, H.; Stang, P.J.; Chi, K.W. Anticancer Activity of Self-Assembled Molecular Rectangles via Arene-Ruthenium Acceptors and a New Unsymmetrical Amide Ligand. Organometallics 2012, 31, 3519-3526.

17. Beyer, R.; Kalaji, M.; Burton, G.K.; Murphy, P.J.; Pereira, V.M.S.C.; Taylor, D.M.; Williams, G.O. Spectroelectrochemical and electrical characterization of low bandgap polymers. Synth. Metals 1998, 92, 25-31.

18. Nenajdenko, V.G.; Baraznenok, I.L.; Balenkova, E.S. Efficient One-Pot Synthesis of Dithieno(dibenzothieno)-Fused Cycloheptanones, Tropones, and Cyclooctanones. J. Org. Chem. 1998, 63, 6132-6136. 
19. Wahab, R.; Kaushik, N.K.; Verma, A.K.; Mishra, A.; Hwang, I.H.; Yang, Y.B.; Shin, H.S.; Kim, Y.S. Fabrication and growth mechanism of $\mathrm{ZnO}$ nanostructures and their cytotoxic effect on human brain tumor U87, cervical cancer HeLa, and normal HEK cells. J. Biol. Inorg. Chem. 2011, 16, 431-442.

20. Kaushik, N.K.; Uhm, H.S.; Choi, E.H. Micronucleus formation induced by dielectric barrier discharge plasma exposure in brain cancer cells. Appl. Phys. Lett. 2012, 100, 084102:1-084102:4.

21. Countryman, P.I.; Heddle, J.A. The production of micronuclei from chromosome aberrations in irradiated cultures of human lymphocytes. Mutat. Res. 1976, 41, 321-332.

22. Tekto, I.V. Computing chemistry on the web. Drug Discov. Today 2005, 10, 1497-1500.

23. Wenlock, M.C.; Austin, R.P.; Barton, P.; Davis, A.M.; Leeson, P.D. A comparison of physicochemical property profiles of development and marketed oral drugs. J. Med. Chem. 2003, $46,1250-1256$.

Sample Availability: Samples of the compounds Di(3-thienyl)methanol and Di(3-thienyl)methane are available from the authors.

(C) 2012 by the authors; licensee MDPI, Basel, Switzerland. This article is an open access article distributed under the terms and conditions of the Creative Commons Attribution license (http://creativecommons.org/licenses/by/3.0/). 